\title{
PERBEDAAN FREKUENSI DIARE ANTARA BAYI YANG DIBERI ASI EKSKLUSIF DENGAN BAYI YANG DIBERI SUSU FORMULA PADA RENTANG USIA 2- 4 BULAN DI WILAYAH KERJA PUSKESMAS KLATEN TENGAH
}

\author{
Putri Rahmitasari, Burhannudin Ichsan, Sahilah Ermawati \\ Fakultas Kedokteran Universitas Muhammadiyah Surakarta \\ Correspondence to : Burhannudin Ichsan \\ Email : Burhannudin.Ichsan@ums.ac.id
}

\begin{abstract}
The main indicator of public health's degree is infant mortility rate (IMR). One of the main things that cause infant mortility is diarrhea. The existence of diarrhea's incidence in infants can be caused due to errors in the form of food other than breast milk feeding at the age of 4 months or the practise of infant feeding with formula milk (replacement feeding). This research was an observational analytic research with cross sectional approach. Samples obtained amounted to 80 respondents who are infants aged 2-4 months in various "posyandu" in the area of Central Klaten. This sample had fulfilled the predetermined criteria. The research instrument used a questionnaire. for the result, there were 21 respondents of 80 respondents obtained who had diarrhea. Respondents of exclusive breastfeeding who had frequency of diarrhea is rarely as many as 5 babies, whereas 1 baby for often category. Respondents of infant formula who had frequency of diarrhea is rarely as many as 12 babies, whereas 3 babies for often category. There were significant differences between infants who were breastfed exclusively with formula-fed infants againts diarrhea frequency indicated by the value of $p=0,032$.
\end{abstract}

Keywords: Frequency of Diarrhea, Exclusive Breast Feeding, Formula Feeding Infant, Infants Aged 2-4 Months

\section{PENDAHULUAN}

Indikator utama derajat kesehatan masyarakat adalah angka kematian bayi (AKB) atau Infant Mortility Rate (IMR) (Notoatmodjo, 2007). AKB di Indonesia masih tergolong tinggi jika dibandingkan dengan AKB di negara-negara anggota ASEAN lainnya, yaitu 4,6 lebih tinggi dari Malaysia, 1,3 lebih tinggi dari Filipina dan 1,8 lebih tinggi dari Thailand. Terdapat tiga penyebab utama kematian bayi yang masih menjadi tantangan besar untuk diatasi. Ketiga hal tersebut adalah Infeksi Saluran Pernapasan Akut (ISPA), komplikasi perinatal dan diare. Gabungan tiga penyebab ini memberikan peran sebesar $75 \%$ terhadap kematian bayi (UNDP, 2007).

Menurut Sunoto (2008) dalam Ariningrum, Sundari \& Riyadina (2009), penyakit diare di Indonesia sampai saat ini masih merupakan salah satu penyakit endemis dan masih sering menimbulkan kejadian luar biasa (KLB) di masyarakat. Penelitian yang dilakukan oleh Aryani di Departemen Kesehatan Anak, Fakultas Kedokteran, Universitas Indonesia, Rumah Sakit Cipto Mangunkusumo selama 1996-1997, menunjukkan bahwa diare akut terjadi pada 85 pasien berusia 2-24 bulan dengan insidensi tertinggi $(42,4 \%)$ pada usia $0-11$ bulan (Roesli, 2005).

Adanya kejadian diare pada balita dapat disebabkan karena kesalahan pemberian makanan. Kesalahan ini dapat berupa bayi yang diberi makanan selain ASI pada usianya yang baru 4 bulan atau adanya praktek pemberian makan bayi dengan susu formula atau replacement feeding (WHO, 2009).

Di seluruh dunia, bayi yang diberikan ASI eksklusif selama 4 bulan pertama kehidupan hanya sekitar kurang dari 35\% (Gibney, 2009). Berdasarkan data yang diperoleh dari profil kesehatan kabupaten/kota di Provinsi Jawa Tengah 
tahun 2008, cakupan pemberian ASI eksklusif hanya sekitar 28,96\%. Angka ini dirasakan masih sangat rendah bila dibandingkan dengan target pencapaian ASI eksklusif tahun 2010 sebesar $80 \%$ (WHO, 2002).

ASI bukan sekedar sebagai makanan, tetapi juga sebagai suatu cairan yang terdiri dari sel hidup seperti sel darah putih dan mengandung antibodi, hormon, faktor-faktor pertumbuhan, enzim, serta zat yang dapat membunuh bakteri dan virus, sedangkan susu formula adalah cairan yang berisi zat mati, yang di dalamnya tidak ada sel hidup seperti pada ASI (Hendrawati et al, 2005).

Susu bubuk formula atau Powdered Infant Formula (PIF) biasanya dibuat dari bahan susu sapi atau produk kedelai dengan proses industri. Selama proses pembuatan, sejumlah nutrisi ditambahkan kedalamnya agar lebih mirip dengan ASI tetapi, kualitasnya tetap berbeda, terutama pada lemak, protein dan ketiadaan faktor antiinfeksi (Depkes, 2008)

Berdasarkan data di atas, penulis tertarik melakukan penelitian untuk mengetahui perbedaan frekuensi diare antara bayi yang diberi ASI eksklusif dan bayi yang diberi susu formula pada rentang usia 2-4 bulan di wilayah kerja puskesmas Klaten Tengah.

Rumusan penelitian ini adalah "Adakah perbedaan frekuensi diare antara bayi yang diberi ASI eksklusif dengan bayi yang diberi susu formula pada rentang usia 2-4 bulan?"

Tujuan dari penelitian ini adalah untuk mengetahui adanya perbedaan frekuensi diare antara bayi yang diberi ASI eksklusif dengan bayi yang diberi susu formula pada rentang usia 2-4 bulan di wilayah kerja puskesmas Klaten Tengah.

Manfaat penelitian ini adalah:

1. Manfaat Teoritis

Hasil penelitian ini dapat menambah wawasan ilmu kedokteran khususnya di bidang kesehatan masyarakat.

2. Manfaat Praktis

a. Hasil penelitian ini dapat digunakan sebagai masukan dalam rangka upaya-upaya pencegahan diare pada balita khususnya di wilayah Klaten Tengah.

b. Hasil penelitian ini dapat digunakan sebagai bahan untuk kampanye ASI eksklusif khususnya ditujukan kepada ibu-ibu yang mempunyai bayi dan balita.

\section{METODE PENELITIAN}

Metode yang dipakai adalah survei analitik dengan rancangan penelitian cross sectional, di mana korelasi antara variabel bebas dan terikat di observasi pada saat yang sama.

Penelitian ini dilakukan di berbagai posyandu di wilayah kerja Puskesmas Klaten Tengah mulai bulan September 2011 sampai bulan Oktober 2011 dengan populasi penelitian meliputi semua bayi usia 2-4 bulan yang bertempat tinggal di Kecamatan Klaten Tengah.

Definisi operasional variabel, diare merupakan suatu keadaan pengeluaran tinja yang tidak normal atau tidak seperti biasanya. Perubahan yang terjadi berupa perubahan peningkatan volume, keenceran dan frekuensi dengan atau tanpa lendir dan darah lebih dari $3 \mathrm{kali} / \mathrm{hari}$ untuk bayi dan anak serta lebih dari 4 kali/hari untuk neonatus. Alat ukur dengan kuesioner. Hasil ukur frekuensi diare : tidak pernah, jarang (riwayat diare sebanyak 1 kali) dan sering (riwayat diare sebanyak lebih dari 1 kali) dengan skala ordinal.

Jenis makanan yang diberikan pada bayi usia 2-4 bulan dalam penelitian ini berupa ASI eksklusif dan susu formula. ASI eksklusif yaitu pemberian ASI secara eksklusif adalah bayi hanya diberi ASI saja tanpa tambahan cairan lain seperti susu formula, air jeruk, teh, air putih dan tanpa tambahan makanan padat seperti pisang, pepaya, bubur susu, biskuit, bubur nasi dan tim selama 4 bulan atau 6 bulan. Pemberian susu formula yaitu bayi diberi makanan berupa ASI tidak eksklusif. Alat ukur : kuesioner, hasil ukur : ASI eksklusif dan susu formula dengan skala nominal.

Instrumen yang digunakan dalam penelitian ini adalah data primer yang berupa kuesioner. Penggunaan kuesioner dalam penelitian ini dengan cara:

1. Wawancara, yaitu peneliti mewawancarai responden secara langsung dengan berpedoman pada kuesioner.

2. Terbimbing, yaitu peneliti mendampingi dan memberikan penjelasan tiap-tiap pertanyaan kepada responden ketika mengisi kuesioner.

3. Pengisian kuesioner tanpa pendampingan, yaitu peneliti memberikan kuesioner kepada responden lewat bidan desa selanjutnya diisi dan dikumpulkan dalam hari yang sama.

Analisis data meliputi pengolahan data penelitian dengan cara editing (penyuntingan), 
coding (pemberian kode), data entry (memasukkan data) dan data cleaning (pembersihan data atau pemeriksaan data) yang selanjutnya akan dianalisis menggunakan program SPSS (Social Package for Social Sciences) 17.0 for windows dengan uji Kolmogorov-Smirnov.

\section{HASIL DAN PEMBAHASAN}

Karakteristik responden berdasarkan jenis kelamin. Mayoritas dari 80 responden yang diperoleh, terdiri atas perempuan yaitu sebanyak 45 bayi atau $56,25 \%$, sedangkan laki-laki sebanyak 35 bayi atau $43,75 \%$.

Karakteristik responden berdasarkan usia bayi. Mayoritas responden berusia 4 bulan yaitu sebanyak 33 bayi atau $41,25 \%$. Kemudian disusul responden berusia 2 bulan sebanyak 31 bayi atau $38,75 \%$ dan sisanya responden berusia 3 bulan yaitu sebanyak 16 bayi atau $20 \%$.

Karakteristik responden berdasarkan pemberian makanan. Mayoritas responden diberikan ASI eksklusif, yaitu sebanyak 47 bayi atau $58,75 \%$ dan sisanya yaitu 33 responden atau $41,25 \%$ diberikan susu formula (ASI tidak eksklusif).

Karakteristik responden berdasarkan kejadian diare. Dari 80 sample yang diperoleh, 21 diantaranya atau $26,25 \%$ pernah mengalami diare dan 59 sisanya yaitu sebesar $73,75 \%$ tidak pernah mengalami diare, sedangkan 21 responden yang pernah mengalami diare tersebut, 6 responden diantaranya adalah bayi ASI eksklusif dan sisanya yaitu 15 responden merupakan bayi susu formula (ASI tidak eksklusif).

Hasil perhitungan statistik perbedaan frekuensi diare antara bayi yang diberi ASI eksklusif dengan bayi yang diberi susu formula.

Berdasarkan hasil uji statistik dengan Kolmogorov-Smirnov Test, menunjukkan bahwa nilai $\mathrm{p}=0.032(\mathrm{p}<0,05)$ sehingga bisa disimpulkan bahwa terdapat perbedaan frekuensi diare yang bermakna antara bayi yang diberi ASI eksklusif dengan bayi yang diberi susu formula.

Tabel 1. Hasil analisis dengan Kolmogorov-Smirnov Test

\begin{tabular}{llllll}
\hline & \multicolumn{3}{c}{ Most Extreme Difference } & Kolmogorov-Smirnov Z & Asymp.Sig. (2-tailed) \\
\cline { 2 - 4 } & Absolute & Positive & Negative & \\
\hline Frekuensi Diare & .327 & .327 & .000 & 1.439 & .032 \\
\hline
\end{tabular}

Tabel 2. Perbedaan frekuensi diare antara bayi yang diberi ASI eksklusif dengan bayi yang diberi susu formula

\begin{tabular}{|c|c|c|c|c|c|c|c|c|c|}
\hline \multirow{3}{*}{ Makanan Bayi } & \multicolumn{6}{|c|}{ Frekuensi Diare } & \multirow{3}{*}{$\begin{array}{c}\text { Jml } \\
\text { Total }\end{array}$} & \multirow{3}{*}{$\mathrm{p}$} & \multirow{3}{*}{$\mathrm{z}$} \\
\hline & \multicolumn{2}{|c|}{ Tidak pernah } & \multicolumn{2}{|c|}{ Jarang } & \multicolumn{2}{|c|}{ Sering } & & & \\
\hline & (n) & $(\%)$ & (n) & $(\%)$ & (n) & $(\%)$ & & & \\
\hline ASI eksklusif & 41 & 69,5 & 5 & 29,4 & 1 & 25,0 & 47 & & \\
\hline Susu formula & 18 & 30,5 & 12 & 70,6 & 3 & 75,0 & 33 & .032 & 1.439 \\
\hline Total & 59 & 100 & 17 & 100 & 4 & 100 & 80 & & \\
\hline
\end{tabular}

Sumber : data primer

Berdasarkan tabel diatas, dari jumlah total 80 responden yang diperoleh, terdapat 17 responden atau $21,25 \%$ yang masuk frekuensi diare berkategori jarang dan 4 responden atau 5\% yang masuk frekuensi diare berkategori sering, sedangkan 59 responden lainnya atau $73,75 \%$ tidak pernah mengalami diare. Bayi yang diberi ASI eksklusif memiliki frekuensi diare dengan kategori jarang sebanyak 5 bayi dan berkategori sering sebanyak 1 bayi sedangkan bayi yang diberi susu formula memiliki frekuensi diare berkategori jarang sebanyak 12 bayi dan berkategori sering sebanyak 3 bayi.
Salah satu hal yang dapat menyebabkan perbedaan kejadian diare dan frekuensi diare tersebut adalah asupan zat gizi yang diberikan ibu kepada bayinya, berbeda satu sama lain. Menurut Roesli (2005), bayi ASI eksklusif ternyata akan lebih sehat dan lebih jarang sakit dibandingkan dengan bayi yang tidak mendapat ASI eksklusif karena di dalam ASI terdapat kolostrum yang berfungsi sebagai zat kekebalan. Kolostrum ini akan melindungi bayi dari penyakit diare. Sejalan dengan Roesli, Budiyanto (2002) mengatakan bahwa ASI mengandung faktor-faktor posistif, yaitu kekebalan dalam bentuk seluler dan humoral 
(cair). Kandungan seluler ASI hampir sama tingginya dalam seluler darah. Daya kekebalan pada umumnya ditujukan terhadap kuman patogen pada bayi yang usianya masih muda, kuman tersebut seperti E.coli dan Enterovirus. Kedua kuman tersebut dapat menyebabkan diare. Keuntungan lain yang terdapat dalam ASI antara lain steril, tersedia dengan suhu optimal, produksi disesuaikan kebutuhan bayi, mengandung antibodi dan tidak menyebabkan alergi ${ }^{(38)}$. Bagi bayi, ASI memberikan zat gizi yang lengkap dan mudah dicerna, melindungi bayi dari infeksi karena banyak mengandung antibodi dan sel darah putih dan memiliki faktor-faktor pertumbuhan dan hormon sehingga dapat menstimulasi pertumbuhan dan maturasi sistem pencernaan bayi, sedangkan pemberian susu formula memiliki banyak kerugian baik bagi bayi maupun ibu, yaitu bayi lebih mudah terkena infeksi saluran cerna dan pernafasan (Matondang et al, 2007).

Hasil penelitian ini sejalan dengan penelitian Herawati (2009) yang mengungkapkan bahwa pola pemberian makanan (feeding) pada bayi memang berpengaruh terhadap terjadinya diare. Hasil ini diperkuat juga oleh Nagib (1998) yang mengungkapkan bahwa kejadian diare pada kelompok bayi $0-4$ bulan non eksklusif lebih besar kemungkinan menderita diare dibandingkan pada kelompok bayi 0-4 bulan yang mendapat ASI eksklusif. Penelitian lain yang dilakukan oleh Suyatno (2000) menunjukkan bahwa praktek pemberian MP-ASI pada 4 bulan pertama kehidupan bayi secara nyata dapat menyebabkan meningkatnya episode diare. Fawzi et al (1997) dalam Tifauziah (2003) juga mengatakan bahwa dampak dari pemberian ASI menunjukkan hubungan dengan berat ringannya (severity) diare dan infeksi lain pada bayi.

Penelitian ini juga memiliki keterbatasan. Keterbatasan penelitian ini berupa tidak terpenuhinya jumlah sample responden yang masuk dalam kriteria pemberian susu formula karena pemberian ASI eksklusif oleh ibu kepada bayinya di berbagai posyandu wilayah kerja Puskesmas Klaten Tengah lebih dominan daripada pemberian ASI tidak eksklusif.

\section{KESIMPULAN DAN SARAN}

Kesimpulan yang dapat diambil dari hasil penelitian ini adalah terdapat perbedaan frekuensi diare yang bermakna antara bayi yang diberi
ASI eksklusif dengan bayi yang diberi susu formula pada rentang usia 2-4 bulan dengan nilai $\mathrm{p}=0,032(\mathrm{p}<0,05)$. Untuk saran, bagi para ibu yang mempunyai bayi dan balita diharapkan selalu menjaga kebersihan dan higienitas terutama saat menyusui dan menyiapkan susu formula bagi bayi agar terhindar dari diare dan penyakit-penyakit infeksi lainnya. penelitian masih mempunyai banyak kekurangan, sehingga perlu dilakukan penelitian lebih lanjut untuk mengetahui keberhasilan pemberian ASI eksklusif terhadap diare dengan jumlah sample lebih besar dari jumlah sample pada penelitian ini.

\section{DAFTAR PUSTAKA}

Ariningrum R., Sundari S \& Riyadina W., 2009. Determinan Penyakit Diare pada Anak Balita di Provinsi Nanggro Aceh Darussalam, Jawa Barat, Nusa Tenggara Barat, Nusa Tenggara Timur, Gorontalo, dan Papua. Buletin Penelitian Sistem Kesehatan. $12: 144$

Budiyanto M., 2002. Gizi dan Kesehatan. Malang : Bayu Media dan UMM Press pp. 180.

Depkes, 2008. Profil Kesehatan Provinsi Jawa Tengah. http://www.depkes.go.id 16 Maret 2011

Dowshen S., Izenberg N \& Bass E., 2002. Panduan Kesehatan Balita Petunjuk Lengkap untuk Orang tua dari Masa Kehamilan Sampai Usia Anak 5 Tahun Buku Kesatu. Jakarta : Rajawali Sport pp. 175-7.

Gibney M.J., 2009. Gizi Kesehatan Masyarakat. Jakarta : Penerbit Buku Kedokteran EGC pp. 325-31.

Hendrawati L., Firmansyah A \& Darwis D., 2005. Macronutrient malabsorption in acute diarrhea : Prevalence and affecting factors. Paediatrica Indonesiana. 45: 9-10

Herawati T., 2009. Pengaruh Pola Pemberian Makanan Bayi Terhadap Kejadian Diare Sampai dengan Usia 6 Bulan di Kabupaten Lombok Timur Provinsi Nusa Tenggara Barat. Universitas Gajah Mada. Tesis.

Matondang C., Munasir Z \& Sumadiono., 2007. Buku Ajar Alergi-Imunologi Anak Edisi Kedua. Jakarta : Balai Penerbit IDAI pp. 158-198.

Nagib M., 1998. Pemberian ASI Eksklusif Ditinjau dari Karakteristik Perilaku Ibu dan Sosial Budaya dengan Kejadian diare Bayi di Kecamatan Masbagik Lombok Timur (NTB). Universitas Gajah Mada. Tesis.

Notoatmodjo S., 2007. Kesehatan Masyarakat Ilmu dan Seni. Jakarta : Rineka Cipta pp. 249252. 
Roesli U., 2005. Mengenal ASI Eksklusif. Jakarta : Trubus Agriwidya pp. 3, 6-15, 24-6 \& 34.

Suyatno, 2000. Pengaruh Pemberian Makanan Pendamping ASI (MP-ASI) Tradisional terhadap Kejadian ISPA, Diare dan Status Gizi Bayi pada 4 (Empat) Bulan Pertama Kehidupannya. Universitas Gajah Mada. Tesis.

Tifauziah N., 2003. Perbedaan Status Gizi, Durasi ISPA dan Diare Bayi Usia 4-6 Bulan Antara Bayi dengan Penyusuan ASI Eksklusif dan ASI tidak Eksklusif di Kabupaten Bantul Yogyakarta. Universitas Gajah Mada. Tesis.

UNDP, 2007. Laporan Perkembangan Pencapaian Millenium Development Goals Indonesia. Jakarta : Kementerian Negara Perencanaan Pembangunan Nasional/Badan Perencanaan Pembangunan Nasional
WHO, 2002. Nutrient Adequacy of Exclusive Breastfeeding for The Term Infant During The First Six Months of Life. http:// www.who.int/nutrition/databases/ infantfeeding/countries/idn.pdf 2 Maret 2011

WHO, 2009. Infant and Young Child Feeding.http:// www.who.int/nutrition/publications/ infantfeeding/infantformulatradeissueseng. pdf 2 Maret 2011 